\title{
PCR DETECTION OF COXIELLA BURNETII FROM BULL SEMEN SAMPLES USED FOR ARTIFICIAL INSEMINATION
}

Yatsentyuk S.P.*, Lazareva E.A., Gorbacheva N.S., Krasnikova M.S., Kozlova A.D. Russian State Center for Animal Feed and Drug Standardization and Quality, Moscow, Russia

Laishevtcev A.I.

Federal Scientific Centre VIEV, Moscow \& Laboratory of Biological Control and Antimicrobial Resistance of the Orel State University named after I.S. Turgenev, Orel, Russia

$$
{ }^{*} \text { E-mail: pcr-lab@vgnki.ru }
$$

\begin{abstract}
444 samples of bull frozen semen used for artificial insemination from local and foreign breeding centers were investigated by PCR for the presence of DNA of Coxiella burnetii. C. burnetii DNA was detected in 32 semen samples from US and was not found in semen straws from local breeding centers and breeding centers of Netherlands and Great Britain. According to the results, it is evident that despite the restrictions and controls on the international movement of semen, bull semen is still a potential source of pathogen transmission.
\end{abstract}

\section{KEY WORDS}

Artificial insemination, Coxiella burnetii, bull semen, PCR.

Coxiella burnetii is an obligate intracellular parasite, a polymorphic gram-negative rodshaped bacterium that causes human $Q$ fever and animal coxieellosis. In animals coxiellosis is often asymptomatic. The pathogen has a tropism for reproductive organs. It plays a role in infertility of cattle and may cause metritis, abortions, prematurity of the fetus. In sick animals, the pathogen is actively released into the external environment with urine, placenta and feces [1].

Outbreaks and sporadic cases of coxiellosis are reported everywhere, especially in countries with developed livestock production. Endemic Areas are the western part of the USA, Australia, Africa, Great Britain, the Mediterranean countries, and the Central Asian republics of the former USSR. In the Russian Federation the disease is registered in more than 50 administrative units. In recent years, a significant increase in the incidence of coxiellosis has been recorded in many countries of the world. The acute form of $Q$ fever in humans is manifested in the form of a flu-like febrile illness, SARS.

C. burnetii is very resistant to environmental influences. Low temperatures (from -4 to -70 degrees Celsius) create particularly favorable conditions for the conservation of bacteria. At the same time, the virulent properties of $\mathrm{C}$. burnetii do not change, or, decreasing during storage, are quickly restored when passaged in laboratory animals. Even a single infective particle can initiate an infection in the animal model [2].

In the 90 s, cases of the detection of $\mathrm{C}$. burnetii in semen of seropositive bulls were described [3].

Artificial insemination (AI) is a successful technique that is used for the breeding of cattle around the world. Modern technologies for the collection of semen for Al involve deep freezing and using diluents and cryo-protectant in order to stay sperm viable. Other substances that can be added to the semen are antibiotics, and an extender, which makes it possible to use the amount of sperm for a greater number of inseminations. However, the widespread sale of doses of sperm increases the potential risk of the spread of infectious diseases. 
Cell culture is still used as a sensitive tool for routine detection of $\mathrm{C}$. burnetii, but this method is laborious and time-consuming. Isolation and handling of the $Q$ fever agent requires rigorous compliance requirements due to pathogen can potentially be used in bioterrorism and its handling is federally regulated.

PCR is a highly sensitive and specific detection method that has been used in different countries for $C$. burnetii detection in milk, blood and animal tissue samples [4-10].

The aim of our work was to investigate the prevalence of $\mathrm{C}$. burnetii in frozen bull semen samples of Russian origin and imported semen straws used for artificial insemination.

\section{MATERIALS AND METHODS OF RESEARCH}

Semen straws were collected from local $(n=211)$ and foreign (Netherlands, Great Britain and the USA) ( $n=233)$ Al centers. Semen sample was diluted $1: 3$ in $0,9 \%$ sodium chloride. DNA was extracted from $100 \mathrm{mkl}$ suspension with RIBO-prep extraction DNA/RNA kit (AmpliSens, Russia). PCR for C. burnetii detection was performed using LSI VetMAX ${ }^{\mathrm{TM}}$ Triplex Coxiella burnetii and Chlamydophila spp. kit (Life Technologies Corporation, France) according to the manufacturer's instructions. All real-time PCR assays were performed on a RotorGene Q (Qiagen, Germany) real-time PCR instrument. Positive samples were re-tested using conventional PCR with primers cocF and $\operatorname{cocR}[10]$, which amplifies the 16S rRNA gene of $C$. burnetii. The amplification was performed in a total volume of $25 \mu \mathrm{L}$ containing 10 mkl of DNA sample, $5 \mathrm{mkl}$ PCR-mix 1 (0.2 mM dNTPs, $10 \mu \mathrm{M}$ each primer), $10 \mathrm{mkl}$ PCR-mix blue (AmpliSens, Russia). The thermal program was carried out on "Tercyc" Multi-block Thermocycler (DNA-technology, Russia) under the following conditions: $94^{\circ} \mathrm{C}$ for $5 \mathrm{~min}$ and then for 42 cycles of $94^{\circ} \mathrm{C}$ for $10 \mathrm{sec}, 60^{\circ} \mathrm{C}$ for $10 \mathrm{sec}, 72^{\circ} \mathrm{C}$ for $10 \mathrm{sec}$ and a final extension at $72^{\circ} \mathrm{C}$ for $3 \mathrm{~min}$. The PCR-amplification products were examined by electrophoresis in a $1.8 \%$ agarose gel, visualized under UV and photographed by gel documentation system. Four positive samples were confirmed by sequencing of the 16S rRNA PCR products using specific primers and the Big Dye ${ }^{\circledR}$ Terminator v1.1 Cycle Sequencing Kit on a GeneAmp PCR System 2720 PCR instrument (Applied Biosystem, USA) and ABI PRISM 3130 Genetic Analyzer automatic sequencer.

\section{RESULTS AND DISCUSSION}

We studied total 444 semen samples of bulls of different meat and dairy breeds, including 211 samples from bulls from Russian breeding centers, 233 samples from foreign breeding centers. No DNA of $C$. burnetii was found in semen samples from local breeding centers and breeding centers of Netherlands and Great Britain. In our study C. burnetii DNA was detected in 32 semen samples from US breeding centers. The presence of pathogen DNA was further confirmed by amplification and sequencing of the 16S rRNA gene using specific primers.

C. burnetii is widespread among domestic animals. Nevertheless, information about the pathogen transmission through the bull semen is still insufficient. Manufacturers of cryoconserved semen for Al use special media for sperm dilution and storage. They increase the volume of sperm, which is of great practical importance for the intensive use of bulls, as well as to protect sperm and support its biological properties. One of the medium often used in US breeding farms includes milk. It should be noted that it is well known about the distribution of C. burnetii with milk [7-9]. It was shown that C. burnetii was found in $1.42 \%$ of milk samples studied in Turkey [10], the frequency of C. burnetii in milk samples studied in Iran using different PCR assays was more than 10\% [11]. C. burnetii was found in $>94 \%$ samples of bulk tank milk from U.S. dairy herds tested during 2001-2003 [9] and $45 \%$ of composite milk samples of lactating cows tested in the U.S. in 2007 [12]. Possibly, the high frequency of DNA C. burnetii detection in semen samples in our study is associated with C. burnetii contaminated milk used in US breeding centers to dilute the sperm. But the cases of the pathogen detection in semen of seropositive bulls indicate the need for additional control of semen production used for Al. 


\section{CONCLUSION}

According to the results, it is evident that despite the restrictions and controls on the international movement of semen, bull semen is still a potential source of pathogen transmission. The results of this study are limited to the PCR-based methods for detection of C. burnetii in the semen samples, so we cannot confirm the viability of the pathogen. In subsequent studies it is better to compare results of PCR methods for $\mathrm{C}$. burnetii detection with results of other methods. However, our results suggest that the risk of transmitting $\mathrm{C}$. burnetii via semen exists and that it would be valuable to test semen batches for the presence of pathogen.

\section{REFERENCES}

1. Panferova Yu.A. Molecular genetic basis of physiology and pathogenicity of Coxiella burnetii / Infection and immunity. 2012., vol. 2., No. 3., pp. 615-626.

2. Ormsbee R, Peacock M, Gerloff R, Tallent G, Wilke D. Limits of rickettsial infectivity / Infect Immun.1978;19:239-245.

3. Kruszewska D., Tylewska-Wierzbanowska S. Isolation of Coxiella burnetiid from bull semen / Research in Veterinary Science 1997, V. 62, Issue 3, P. 299-300.

4. Lorenz H., Jäger C., Willems H., Baljer G. PCR Detection of Coxiella burnetii from different clinical specimens, especially bovine milk, on the basis of DNA preparation with a silica matrix /Appl Environ Microbiol. 1998 Nov; 64(11): 4234-4237.

5. Willems H, Thiele D, Fröhlich-Ritter R, Krauss H. Detection of Coxiella burnetii in cow's milk using the polymerase chain reaction (PCR) / J Vet Med Ser B.1994;41:580-587.

6. S. R. Klee, J. Tyczka, H. Ellerbrok, T. Franz, S. Linke, G. Baljer, B. Appel Highly sensitive real-time PCR for specific detection and quantification of Coxiella burnetii BMC Microbiol. 2006; 6: 2. Published online 2006 Jan 19.doi:10.1186/1471-2180-6-2.

7. Guatteo R, Beaudeau F, Joly A, Seegers H: Coxiella burnetii shedding by dairy cows. Vet Res. 2007, 38: 849-860.

8. Angerholm J. Coxiella burnetii associated reproductive disorders in domestic animals-a critical review / Acta Veterinaria Scandinavica 2013. V. 55:13

9. Kim, S.G., Kim, E.H., Lafferty, C.J., Dubovi, E.: Coxiella burnetiid in bulk tank milk samples, United States /Emerg. Infect. Dis.,2005; V. 11: 619-621.

10. Gulmez Saglam, M. Sahin Coxiella burnetii in samples from cattle herds and sheep flocks in the Kars region of Turkey/ Veterinarni Medicina, 61, 2016 (1): 17-22.

11. Kargar M, Rashidi A, Doosti A, Najafi A, Ghorbani-Dalini S. The Sensitivity of the PCR Method for Detection of Coxiella burnetii in the Milk Samples, Zahedan J Res Med Sci. 2015; 17(6): -.doi: 1.17795/zjrms988.

12. Barlow J., Rauch B., Welcome F., Sung Guk Kim, Dubovi E., Schukken Y. Association between Coxiella burnetii shedding in milk and subclinical mastitis in dairy cattle / Vet. Res. 2008., V. 39:23. P 7-9. 